\title{
Assessing and Improving General English University Students' Main Sub-skills of Reading Compression: A Case of University of Bojnord*
}

\author{
Majid Elahi Shirvan \\ University of Bojnord, Bojnord, Iran
}

\begin{abstract}
General English course at Iranian universities has always been a controversial issue since the students taking this course are rather weak in English proficiency and need more authentic instructions based on accurate need analysis. The materials applied in this course are mainly focused on reading comprehension. Thus, the purpose of the present study was to improve General English university students' main sub-skills of reading comprehension and see the effect of the possible changes in terms of time and the fields of study of the students. To do this, 168 university students taking General English course at university of Bojnord, including humanities, engineering, physical education, and sciences, received instruction on the main sub-skills of reading comprehension after taking a pre-test sample TOELF section of reading comprehension. After 16 sessions of 90 minute instruction, they took the post-test section of TOEFL sample of reading comprehension. Mixed between within subject analysis of variance was used to assess the impact of instruction for the four groups of students from pre-test to post-test. The findings of the study indicated that the effect of instruction in terms of time, from pre-test to post-test, and the interaction of time and fields of study were significant. Besides, changes for 10 sub-skills were the same among the four fields of study.
\end{abstract}

Keywords: General English, reading comprehension, skills

\section{Introduction}

The problem related to the reading comprehension is one of the most serious problems in higher. However, incapability of reading comprehension is often not recognized by students and lecturers until they entrance into academic courses. Levine, Ferenz, and Reves (2000) hold: "The ability to read academic texts is considered one of the most important skills that university students of English as a Second Language (ESL) and English as a Foreign Language (EFL) need to acquire" (p. 1). There has been a long productive line of L2 reading research establishing the central importance of reading skills and strategies in successful processing in reading comprehension (Anderson, 1991; Block, 1992; Ikeda \& Takeuchi, 2006; McNeil, 2011; Zhang \& Wu, 2009). However, many students come into higher education with no training for the reading skills. Thus, when forced to read a pervasive mass of texts, they often utilize fruitless and inefficient strategies and skills (Arnold, 2009;

\footnotetext{
* Acknowledgements: I gratefully acknowledge the project reported here was supported by a grant-in-aid of research from University of Bojnord in 2015 (contract code: 93/59/10509), without which this research would not have been possible. Majid Elahi Shirvan, Ph.D., English Language Department, University of Bojnord.
} 
Anmarkrud, Bråten, \& Strømsø, 2014; Bråten \& Strømsø, 2011; Kobayashi, 2010; Mason, Scirica, \& Salvi, 2006). The failure in reading comprehension might be due to students' low level of reading strategy awareness and lack of metacognitive knowledge (Berkowitz \& Cicchelli, 2004; Chen, Gualberto, \& Tameta, 2009). In addition, the Iranian education system concentrates still on knowledge aspects of learning rather than practical aspects. Hence, students are coming from the insufficient task demands of high school and the fact that they are using inefficient skills for reading comprehension (Elahi \& Taherian, 2015).

Moreover, as all the interactive approaches to learning second language maintain, the aim of learning second language is communication. Therefore, communicative competence should be the target of learning English. One channel of communication which seems pivotal for the general English language learners at university is reading comprehension for several reasons. First of all, they are supposed to be prepared for academic English exams like TOLIMO (The Test of Language by the Iranian Measurement Organization), TELP (Test of English Language Proficiency), and MSRT (Ministry of Science, Research and Technology) in which reading comprehension part plays an important role in their performance. Second, they look and search for different articles related to their field of study; thus, reading comprehension seems more significant than the other skills like speaking, listening, and writing. Therefore, enhancing reading skills of these students can pave the way for their achievement in their own major. Besides, these students just take a two unit course of general English which does not suffice to guarantee their performance. In addition, they do not have General English courses at Masters or Ph.D. level. So, the need for a comprehensive framework for the development of their reading comprehension skills is needed. Yet, there is little evidence to suggest that students at any level will acquire these skills and strategies if they have not been explicitly taught (Anmarkrud, Bråten, \& Strømsø, 2014).

Therefore, the purpose of this article is to answer the following question:

(1) Is the training course of the main sub-skills of English language reading comprehension significant for the university students' general English? Is there a significant difference between the pre-test and post-test of the four groups of engineering, humanities, sciences, and physical education in the main sub-skills of English language reading comprehension?

(2) Is the change in participants' main sub-skills of reading comprehension the same for the four groups of students?

\section{Review of the Literature}

\section{Communicative Competence}

Communicative competence is one of the important factors that enable people to achieve their goals in social life. It plays a pivotal for interactional purposes and intercultural exchanges. "Communicative competence" is a term coined by the anthropological linguist Hymes $(1967,1972)$; he introduces this concept in response to the theories of the formal linguist Noam Chomsky (Chomsky, 1964), who emphasizes on linguistic competence and holds that the social factors are not considerate in the linguistics domain, that is, an innate language mechanism is adequate for acquiring language. Hymes (1972) contended that language acquisition is not context-free. Therefore, despite the linguistic competence, one also requires concept of sociolinguistic competence, which is defined as the proper use of language in an appropriate context.

At the same time, some applied linguists and language teachers tried to develop and elaborate a model of communicative competence for curriculum design in response to grammar translation and audio-lingual 
approaches to language pedagogy. Among them were Canale and Swain (1980); they state that beside the linguistic competence and sociolinguistic competence, the strategic competence has an important role in language acquisition. Nevertheless, they referred to "linguistic competence" as "grammatical competence". The strategic competence is defined as the ability to deal with communicative situation and to go on the communicative channel open. Indeed, strategic competence is the ability to compensate for deficient knowledge of rules of interactions.

Oxford (2003) argued that learners who use a range of efficient language strategies learn better and faster compared to learners who do not use a diversity of language learning strategies. As a result, teachers should integrate some strategy training into their language classes. Therefore, when teachers deal with a reading passage, ways of understanding relations between parts of text through lexical cohesion devices, ways of guessing the meaning of words in context, etc., can be discussed.

\section{Reading Comprehension}

Reading comprehension has been defined in various ways at different times. For instance, in the audio-lingual pedagogy, it was regarded as a tool for teaching other aspects of language such as vocabulary, grammar, and pronunciation. Later, reading comes to be considered as a psycholinguistic guessing game under the impact of Smith (1996) and Goodman (1967). The emphasis was on the reader's active processes while engaging with the text. It was a top-down approach in which readers applied prior knowledge to predict meaning. Then, the reader read to confirm or reject his/her hypothesis. With regard to this view towards reading, a focus on reading strategies and skills implemented by applied linguistics in order learners could process text in a quick, purposeful, comprehending, flexible, and gradually developing way (Grabe, 2009). More recently, L2 studied point out that the lower-skills have also important role in reading comprehension. For these reasons L2 researchers highlighted the importance of the role of both top-down processing approach and bottom-up processing approach through the lens of an interactive model. These involve interaction between lower level skills, such as such as decoding and word recognition, automatic word recognition, sound-word correspondence, and higher level cognitive skills, such as using schemata, forming a gestalt of the whole text, etc. According to literature, for this study reading comprehension involves an active meaning construction process through interactions between a reader and a text involving both lower-order skills and higher-order skills.

\section{Reading Sub-skills}

Many researchers have explored the use of EFL/ESL reading skills among learners (Poole, 2005; Karbalaei, 2010; Li, 2010). According to Barnett (1988), reading strategies are processes in which readers utilize in order to comprehend what they are reading. Some of these strategies are skimming, scanning, guessing word meanings from context, etc. She holds that learners who are using effective reading skills would comprehend the reading better compared with students who do not use suitable reading skills. Later, Carrell (1998) adds that strategies are conscious cognitive processes. Indeed, a conscious learner has the ability to distinguish between strategies that are effective or ineffective for specific reading situation. Moreover, they are able to monitor their reading, which aids in facilitating their comprehension of what they read (Paris, Lipson, \& Wixson, 1983).

Reading "skills" and reading "strategies" are sometimes used interchangeably and the distinction between them is not always clear. "It is not always easy to distinguish skills from strategies" (Hudson, 2007, p. 77). According to Rupp, Ferne, and Choi (2006), "strategies" are conscious procedures which are used intentionally for successful reading, while "skills" are unconscious automatic abilities that improve comprehension. 
According to Hudson (2007), the work of Munby (1978) reflects the research into the hierarchy of L2 reading comprehension sub-skills. Munby's list "has had enormous influence in the area of the teaching and testing of English as a Foreign Language" (Alderson, 2005, p. 9). Munby distinguishes the following reading microskills (Alderson, 2005, pp. 10-11):

- Recognizing the script of a language;

- Deducing the meaning and use of unfamiliar lexical items;

- Understanding explicitly stated information;

- Understanding information when not explicitly stated;

- Understanding conceptual meaning;

- Understanding the communicative value of sentences;

- Understanding relations within the sentence;

- Understanding relations between parts of text through lexical cohesion devices;

- Understanding cohesion between parts of a text through grammatical cohesion devices;

- Interpreting text by going outside it;

- Recognising indicators in discourse;

- Identifying the main point or important information in discourse;

- Distinguishing the main idea from supporting details;

- Extracting salient to summarise (the text, an idea);

- Extracting relevant points from a text selectively;

- Using basic reference skills;

- Skimming;

- Scanning to locate specifically required information;

- Transcoding information to diagrammatic display.

Among these micro-skills, the following five sub-skills are among the most commonly used sub-skills in teaching and assessing reading comprehension in these two decades.

\section{Making Inferences}

Inferring refers to reading between the lines. In this regard, students should to use their prior knowledge along with information from the text to achieve their own comprehension (Serafini, 2004). Cain, Oakhill, and Lemmon (2004) state that, inference making has a pivotal role in representing the text as an integrated and coherent text. Many studies have been investigating the relationship between inference making and comprehension skill (Cain, Oakhill, \& Lemmon, 2004; Cain \& Towse, 2008; Haenggi, Gernsbacher, \& Bolliger, 1994; Oakhill, 1993). Cain, Oakhill, Barnes, and Bryant (2001) investigated the relationship between reading comprehension and inference-making ability. They state that there is a strong relationship between them even. Moreover, according to Cain and Towse (2008), "Poor reading comprehenders' language do not have the ability to make inferences, and thus they might be faced to difficulties in reading comprehension" (p. 1539).

\section{Scanning and Skimming}

Brown (2004) believes that scanning and skimming are "the two most valuable reading strategies for learners" (p. 293). Scanning is the ability to explore rapidly in order to extract a specific piece of information (e.g., names, dates...) without reading the whole text. Skimming, on the other hand, refers to reading quickly through a text to get a general picture of it (Brown, 2004). Scanning needs less attention to the text than skimming does 
(Nuttall, 2005). Duggan and Payne (2009) conducted a study on the process and efficiency of text skimming under time pressure. They found that skimming is a facilitative sub-skill that can be used to get the main idea of a passage. They showed that when readers are under time pressure, "they are indeed able to gain a greater understanding of a text by skimming rather than by reading linearly through an imposed half of the text" (p. 240).

\section{Guessing the Meaning of Unknown Words}

When readers are facing with an unknown word, they might use different strategies, such as looking it up in a dictionary, guessing its meaning, or ignoring it. Kaivanpanah and Alavi (2008) hold that it is most common for readers to guess the meaning of the unknown word. The ability to guess the meaning is affected by the following four textual variables: (1) the characteristics of the word itself; (2) the level of text difficulty; (3) the presence of contextual clues; and (4) topic familiarity (Kaivanpanah \& Alavi, 2008). According to Nuttall (2005), readers who can guess the unknown vocabulary by the context "have a powerful aid to comprehension and will ultimately read more quickly" (Nuttall, 2005, p. 72).

\section{Predicting}

One strategy for enhancing comprehension is predicting, which aids the reader to set an aim for his/her reading. This strategy permits student for more interaction, which raises students' interest and facilitates their understanding of the passage (Oczkus, 2003).

\section{Pronoun Resolution}

Understanding pronoun referent is regarded as an important factor of reading comprehension (Al-Jarf, 2001; Badecker \& Straub, 2002; Crawley \& Stevenson, 1990; Demel, 1990; Huang, 2005; Pretorius, 2005; Wolf, Gibson, \& Desmet, 2004). In a study by Badecker and Straub (2002) on anaphoric resolution and text comprehension, she found a significant positive relationship between overall text comprehension and coreferential tie comprehension for readers of German. Furthermore, Huang (2005) explored the relationship between referential understanding and academic reading comprehension among EFL college students. The results indicated a significant relationship between them. In another study, Sweet and Snow (2003) found that the skilled readers need to understand the coreferent whenever there is a pronoun in the text. To comprehend a text, it is more important to understand the relationships between propositions in that text than just understanding each unique sentence in it (Huang, 2005). Therefore, Rose (2011) states that "it is no surprise then, that pronouns get early treatment in most English language teaching curricula” (p. 1).

\section{Language Learning at Universities in Iran}

Iran is a religious country containing almost no native speakers of English and few number of tourism. In Iran English is the dominated language of the foreign trade, international conferences, air traffic in international airport, and sea navigation. Considering the growth of international relations of Iran with other nations and the extended interest towards today growing technology and science through the world, learning English language especially reading skills has found a greater importance compared to previews years.

The situation in Iran is as follow: In high school, reading comprehension instruction is limited to the assignment of a reading passage, accompanied by a number of short comprehensive questions or multiple-choice questions relating to the passage (personal experience and observation). In universities, non-English majors study English in a maximum of six credits: three credits of general English instruction and three credits of ESP in which they focus on their field related English texts and learn the related terminology. 
However, at the university level, it is often assumed that students have the skills and strategies needed to successfully comprehend expository text. Yet, there is little evidence to suggest that students at any level will acquire these skills and strategies if they have not been explicitly taught.

\section{Method}

\section{Participants}

One hundred and sixty-eight university students (41 physical education, 43, engineering, 38 humanities, and 46 sciences) at University of Bojnord, Iran participated in this study. Their age ranged from 18 to 31 with the mean age of 20.82 were females, 75 were males, and 11 did not report their gender. All the participants took a three credit unit of general English at University of Bojnord. They had no background in learning English at institutes and had only six years of background in learning English at high school. Their native language was Persian, Turkish, and Kurdish.

\section{Instrument}

A sample TOEFL test of reading comprehension consisting of 50 items was used as the pre-test and post-test exam for the current study. It was derived from Actual TOEFL Tests (2005). The Cronbach alpha coefficient of this test turned out to be 0.93 indicating a high level of reliability. Table 1 illustrates the underlying sub-skills of reading comprehension for each item.

Table 1

Underlying Sub-skills of Reading Comprehension for Each Item of Reading Comprehension Sample Test

\begin{tabular}{ll}
\hline Skills $(\mathrm{N}=13)$ & Questions (N=50) \\
\hline Deducing the meaning and use of unfamiliar lexical items & Q1, Q20, Q31 \\
Understanding information when not explicitly stated & Q11 \\
Distinguishing the main idea from supporting details & Q4, Q5, Q12, Q22, Q25, Q33, Q36, Q47 \\
Understanding relations within the sentence & Q18, Q28, Q37 \\
Understanding cohesion between parts of a text through grammatical cohesion devices & Q45 \\
Using basic reference skills & Q8, Q14, Q26, Q34, Q44 \\
Understanding conceptual meaning & Q9, Q10, Q26, Q41 \\
Extracting salient to summarize (the text, an idea) & Q16 \\
Understanding relations between parts of text through lexical cohesion devices & Q6, Q13, Q17, Q23, Q24, Q35 \\
Extracting relevant points from a text selectively & Q3, Q7, Q15, Q32, Q39, Q42, Q48 \\
Skimming & Q2, Q21, Q27, Q38, Q43, Q46 \\
Identifying the main point or important information in discourse & Q19, Q49 \\
Scanning to locate specifically required information & Q30, Q40, Q50 \\
\hline
\end{tabular}

\section{Interview}

Semi-structured interviews were conducted with 10 students of each group to gain a better understanding of the dynamics of the instruction and possible changes students might undergo regarding the main sub-skills of reading comprehension.

\section{Data Collection}

First of all, for the sake of homogeneity in the participants, only those students who had no background in learning English at the language institutes were selected. Two classes for each major and in general eight classes including majors like engineering, physical education, sciences, and humanities participated in the study. 
They were given the pre-test of reading section of TOEFL before the beginning of the course. The whole semester, from September 2014 to December 2014, 16 sessions, was allocated to improve the basic skills of reading comprehension. Teachers of these four groups were different but they were trained and given sufficient instructions to cover teaching the reading skills in the same way to reduce any possible unreliability on the part of teaching methods to a minimum. At the end of the course, a post-test of reading comprehension, sample reading section of TOEFL was given to the participants.

\section{Data Analysis}

The sub-skills of reading comprehension was converted to a 0 to 10 score. Mixed between within design was used to check the difference between the pre-tests and post-tests among the four groups of students. All these analyses were conducted using SPSS 22. Besides the reports of the interview were codes and qualitatively analyzed from an ecological perspective.

\section{Results}

Table 2 indicates the main sub-skills of reading comprehension at the time of pre-test and post-test. The main question related to this part is whether the changes from pre-test to post-test for the 13 sub-skills are significant or not.

Table 2

Within Subject Factors

\begin{tabular}{|c|c|c|}
\hline Measure & Time & Dependent variable \\
\hline \multirow{2}{*}{ Deducing. Meaning } & 1 & Pre. Skill 1 \\
\hline & 2 & Post Skill 1 \\
\hline \multirow{2}{*}{ Understanding. Information } & 1 & Pre. Skill 2 \\
\hline & 2 & Post Skill 2 \\
\hline \multirow{2}{*}{ Distinguishing. Main. Supporting } & 1 & Pre. Skill 3 \\
\hline & 2 & Post Skill 3 \\
\hline \multirow{2}{*}{ Understanding. Relation. Sentences } & 1 & Pre. Skill 4 \\
\hline & 2 & Post Skill 4 \\
\hline \multirow{2}{*}{ Understanding. Cohesion } & 1 & Pre. Skill 5 \\
\hline & 2 & Post Skill 5 \\
\hline \multirow{2}{*}{ Basic. Reference. Skill } & 1 & Pre. Skill 6 \\
\hline & 2 & Post Skill 6 \\
\hline \multirow{2}{*}{ Understanding. Conceptual } & 1 & Pre. Skill 7 \\
\hline & 2 & Post Skill 7 \\
\hline \multirow{2}{*}{ Extracting. Salient } & 1 & Pre. Skill 8 \\
\hline & 2 & Post Skill 8 \\
\hline \multirow{2}{*}{ Understanding. Relation. Between. Sentences } & 1 & Pre. Skill 9 \\
\hline & 2 & Post Skill 9 \\
\hline \multirow{2}{*}{ Extracting. Relevant } & 1 & Pre. Skill 10 \\
\hline & 2 & Post Skill 10 \\
\hline \multirow{2}{*}{ Skimming } & 1 & Pre. Skill 11 \\
\hline & 2 & Post Skill 11 \\
\hline \multirow{2}{*}{ Identifying. Main. Point } & 1 & Pre. Skill 12 \\
\hline & 2 & Post Skill 12 \\
\hline \multirow{2}{*}{ Scanning } & 1 & Pre. Skill 13 \\
\hline & 2 & Post Skill 13 \\
\hline
\end{tabular}


Table 3 shows the between subject factors which are the main fields of study including physical education, engineering, humanities, and sciences. As seen in the Table, the number of students for the fields of physical education, engineering, humanities, and sciences are 41, 43, 38, and 46 respectively. The main question related to this part is whether the changes of skills from pre-test to post-test are the same for the students of these fields of study or not.

Table 3

\section{Between Subject Factor}

\begin{tabular}{lll}
\hline Field of study & Value label & Number \\
\hline Physical education & 1 & 41 \\
Engineering & 2 & 43 \\
Humanities & 3 & 38 \\
Sciences & 4 & 46 \\
\hline
\end{tabular}

Table 4 indicates the main descriptive statistics of the sub-skills of reading comprehension for the students of the four fields of study including the mean and standard deviation at the pre-test and post-test. The question is whether these mean differences for these groups of students are large enough to be considered significant.

Table 4

Descriptive Statistics of the Main Sub-skills of Reading Comprehension

\begin{tabular}{|c|c|c|c|c|c|c|}
\hline \multirow{2}{*}{ Skills } & \multirow{2}{*}{ Field of study } & \multirow{2}{*}{$\mathrm{N}$} & \multicolumn{2}{|c|}{ Pre skills } & \multicolumn{2}{|c|}{ Post skills } \\
\hline & & & Mean & Std. deviation & Mean & Std. deviation \\
\hline \multirow{5}{*}{1} & Physical education & 41 & 3.76 & 1.35 & 4.24 & 1.98 \\
\hline & Engineering & 43 & 4.33 & 2.03 & 6.56 & 1.56 \\
\hline & Humanities & 38 & 2.32 & 1.09 & 4.76 & 1.63 \\
\hline & Sciences & 46 & 4.80 & 2.30 & 6.76 & 1.35 \\
\hline & Total & 168 & 3.86 & 2.00 & 5.67 & 1.96 \\
\hline \multirow{5}{*}{2} & Physical education & 41 & 3.73 & 1.45 & 7.34 & 1.31 \\
\hline & Engineering & 43 & 3.86 & 1.52 & 7.12 & 1.34 \\
\hline & Humanities & 38 & 3.82 & 1.52 & 5.00 & 1.63 \\
\hline & Sciences & 46 & 3.85 & 1.76 & 7.00 & 1.22 \\
\hline & Total & 168 & 3.82 & 1.54 & 6.66 & 1.65 \\
\hline \multirow{5}{*}{3} & Physical education & 41 & 4.66 & 1.62 & 7.12 & 1.47 \\
\hline & Engineering & 43 & 4.23 & 1.63 & 6.00 & 1.86 \\
\hline & Humanities & 38 & 3.84 & 1.60 & 5.00 & 1.69 \\
\hline & Sciences & 46 & 4.85 & 2.06 & 7.00 & 1.22 \\
\hline & Total & 168 & 4.42 & 1.78 & 6.23 & 1.77 \\
\hline \multirow{5}{*}{4} & Physical education & 41 & 3.46 & 1.38 & 5.83 & 1.61 \\
\hline & Engineering & 43 & 3.95 & 1.63 & 5.81 & 1.94 \\
\hline & Humanities & 38 & 3.95 & 1.70 & 6.82 & 1.43 \\
\hline & Sciences & 46 & 3.91 & 1.96 & 6.80 & 1.43 \\
\hline & Total & 168 & 3.82 & 1.68 & 6.32 & 1.68 \\
\hline \multirow{5}{*}{5} & Physical education & 41 & 3.05 & 1.13 & 6.85 & 1.35 \\
\hline & Engineering & 43 & 3.02 & 1.33 & 6.81 & 1.56 \\
\hline & Humanities & 38 & 2.00 & 0.95 & 4.92 & 1.71 \\
\hline & Sciences & 46 & 3.07 & 1.52 & 6.91 & 1.36 \\
\hline & Total & 168 & 2.81 & 1.33 & 6.42 & 1.69 \\
\hline
\end{tabular}


(Table 4 continued)

\begin{tabular}{|c|c|c|c|c|c|c|}
\hline \multirow{2}{*}{ Skills } & \multirow{2}{*}{ Field of study } & \multirow{2}{*}{$\mathrm{N}$} & \multicolumn{2}{|c|}{ Pre skills } & \multicolumn{2}{|c|}{ Post skills } \\
\hline & & & Mean & Std. deviation & Mean & Std. deviation \\
\hline \multirow{5}{*}{6} & Physical education & 41 & 2.00 & 0.77 & 6.41 & 1.64 \\
\hline & Engineering & 43 & 2.09 & 0.92 & 5.88 & 2.00 \\
\hline & Humanities & 38 & 2.00 & 0.87 & 4.26 & 1.81 \\
\hline & Sciences & 46 & 2.00 & 0.84 & 6.66 & 1.43 \\
\hline & Total & 168 & 2.02 & 0.84 & 5.85 & 1.94 \\
\hline \multirow{5}{*}{7} & Physical education & 41 & 3.80 & 1.53 & 6.80 & 1.54 \\
\hline & Engineering & 43 & 3.42 & 1.38 & 6.81 & 1.80 \\
\hline & Humanities & 38 & 3.32 & 1.39 & 5.84 & 1.73 \\
\hline & Sciences & 46 & 6.61 & 1.46 & 6.85 & 1.41 \\
\hline & Total & 168 & 5.85 & 1.94 & 6.60 & 1.65 \\
\hline \multirow{5}{*}{8} & Physical education & 41 & 4.83 & 1.65 & 6.85 & 1.50 \\
\hline & Engineering & 43 & 4.81 & 1.69 & 5.72 & 1.98 \\
\hline & Humanities & 38 & 3.82 & 1.67 & 5.87 & 1.64 \\
\hline & Sciences & 46 & 4.80 & 1.98 & 6.87 & 1.42 \\
\hline & Total & 168 & 4.56 & 1.79 & 6.35 & 1.72 \\
\hline \multirow{5}{*}{9} & Physical education & 41 & 3.90 & 1.30 & 7.22 & 1.25 \\
\hline & Engineering & 43 & 3.91 & 1.55 & 5.30 & 2.01 \\
\hline & Humanities & 38 & 3.92 & 1.63 & 4.32 & 1.06 \\
\hline & Sciences & 46 & 3.91 & 1.71 & 7.30 & 1.28 \\
\hline & Total & 168 & 3.91 & 1.54 & 6.10 & 1.92 \\
\hline \multirow{5}{*}{10} & Physical education & 41 & 3.44 & 1.53 & 6.54 & 1.64 \\
\hline & Engineering & 43 & 3.95 & 1.93 & 6.53 & 1.86 \\
\hline & Humanities & 38 & 2.95 & 1.33 & 5.53 & 2.03 \\
\hline & Sciences & 46 & 3.91 & 1.63 & 6.52 & 1.88 \\
\hline & Total & 168 & 3.59 & 1.66 & 6.30 & 1.89 \\
\hline \multirow{5}{*}{11} & Physical education & 41 & 3.46 & 1.36 & 6.51 & 1.48 \\
\hline & Engineering & 43 & 3.91 & 1.46 & 6.91 & 1.77 \\
\hline & Humanities & 38 & 3.92 & 1.96 & 5.92 & 1.65 \\
\hline & Sciences & 46 & 3.91 & 1.56 & 6.91 & 1.57 \\
\hline & Total & 168 & 3.80 & 1.59 & 6.59 & 1.65 \\
\hline \multirow{5}{*}{12} & Physical education & 41 & 3.29 & 1.52 & 6.32 & 1.75 \\
\hline & Engineering & 43 & 3.05 & 1.15 & 6.81 & 1.89 \\
\hline & Humanities & 38 & 3.00 & 1.48 & 5.82 & 1.57 \\
\hline & Sciences & 46 & 3.02 & 1.69 & 6.83 & 1.37 \\
\hline & Total & 168 & 3.09 & 1.47 & 6.47 & 1.69 \\
\hline \multirow{5}{*}{13} & Physical education & 41 & 3.44 & 1.18 & 6.34 & 1.83 \\
\hline & Engineering & 43 & 3.93 & 1.51 & 6.56 & 1.90 \\
\hline & Humanities & 38 & 3.92 & 1.58 & 6.00 & 1.61 \\
\hline & Sciences & 46 & 3.91 & 1.64 & 7.00 & 1.22 \\
\hline & Total & 168 & 3.80 & 1.49 & 6.50 & 1.68 \\
\hline
\end{tabular}

Table 5 indicates Box's test of equality of covariance matrices. It tests the null hypothesis that the observed covariance matrices of the dependent variables are equal across the main four fields of study. Table 5 shows a Sig. value bigger than .05. Thus, this assumption has not been violated. 
Table 5

Box's Test of Equality of Covariance Matrices

\begin{tabular}{ll}
\hline Box's M & 1645.007 \\
F & 1.110 \\
df1 & 1053 \\
df2 & 54374.265 \\
Sig. & .583 \\
\hline
\end{tabular}

Table 6

Tests of Within Subjects Effects

\begin{tabular}{lllllll}
\hline Within subjects effect & & Value & F & Hypothesis df & Error df & Sig. \\
\hline \multirow{4}{*}{ Time } & Pillai's Trace & .947 & $210.884^{\mathrm{c}}$ & 13.000 & 152.000 & .000 \\
& Wilks' Lambda & .053 & $210.884^{\mathrm{c}}$ & 13.000 & 152.000 & .000 \\
& Hotelling's Trace & 18.036 & $210.884^{\mathrm{c}}$ & 13.000 & 152.000 & .000 \\
& Roy's Largest Root & 18.036 & $210.884^{\mathrm{c}}$ & 13.000 & 152.000 & .000 \\
\hline \multirow{5}{*}{ Time $^{*}$ field of study } & .706 & 3.643 & 39.000 & 462.000 & .000 \\
& Pillai's Trace & .417 & 3.967 & 39.000 & 450.852 & .000 \\
& Wilks' Lambda & 1.118 & 4.318 & 39.000 & 452.000 & .000 \\
& Hotelling's Trace & .826 & $9.789^{\mathrm{d}}$ & 13.000 & 154.000 & .000 \\
\hline
\end{tabular}

Table 6 indicates the main effects and interaction effects of time and field of study. Before assessing the main effects, the interaction effect should be assessed. The question is whether there is the same change in scores over time in all the 13 sub-skills of reading comprehension for the students of the four fields of study. All of the multivariate tests have yielded the same results. In this case, the interaction effect is statically significant $(\mathrm{p}<0.05)$. In addition, all the multivariate tests indicate that the main effect of time is significant ( $\mathrm{p}$ $<0.05$ ). This shows that the change in the sub-skills of reading comprehension section of TOEFL across the two time periods (pre-test and post-test) is statistically significant.

Table 7

Tests of Within Subjects Effects

\begin{tabular}{lll}
\hline Within subjects effect & & Partial eta squared \\
\hline \multirow{3}{*}{ Time } & Pillai's Trace & .947 \\
& Wilks' Lambda & .947 \\
& Hotelling's Trace & .947 \\
& Roy's Largest Root & .947 \\
\hline \multirow{2}{*}{ Time field of study } & Pillai's Trace & .235 \\
& Wilks' Lambda & .253 \\
& Hotelling's Trace & .271 \\
& Roy's Largest Root & .452 \\
\hline
\end{tabular}

Table 7 indicates the effects size of the results of significance of multivariate tests. The values of partial eta squared obtained for time in this study are above .94. Based on the guidelines proposed by Cohen (1988), values above .14 are considered large. Thus, the values of the present partial eta squared in this study suggest a very large effect size.

Table 8 indicates between subject effects. In other words, it shows whether the differences in the mean scores in the post-test of all the main sub-skills among the students of the four fields of study are statistically 
large enough to be considered significant or not. As seen in Table 8, the Sig. value for all the skills except skimming, identifying the main point, and scanning is less than the alpha level of .05. Thus, it is concluded that the main effect for group is for 10 sub-skills of reading comprehension significant. Besides, the values for partial eta squared ranges from moderate .06 to large .14 .

Table 8

Tests of Between Subjects Effects

\begin{tabular}{|c|c|c|c|c|c|c|c|}
\hline Source & Measure & $\begin{array}{l}\text { Type III sum } \\
\text { of squares }\end{array}$ & $\mathrm{df}$ & Mean square & $\mathrm{F}$ & Sig. & $\begin{array}{l}\text { Partial eta } \\
\text { squared }\end{array}$ \\
\hline \multirow{13}{*}{ Intercept } & Deducing. Meaning & 7358.035 & 1 & 7358.035 & 2785.313 & .000 & .944 \\
\hline & Understanding. Information & 9090.914 & 1 & 9090.914 & 3957.804 & .000 & .960 \\
\hline & Distinguishing. Main. Supporting & 9527.302 & 1 & 9527.302 & 3052.649 & .000 & .949 \\
\hline & Understanding. Relation. Sentences & 8586.883 & 1 & 8586.883 & 3288.930 & .000 & .953 \\
\hline & Understanding. Cohesion & 7013.583 & 1 & 7013.583 & 4041.476 & .000 & .961 \\
\hline & Basic. Reference. Skill & 5106.477 & 1 & 5106.477 & 2571.849 & .000 & .940 \\
\hline & Understanding. Conceptual & 8259.808 & 1 & 8259.808 & 3887.790 & .000 & .960 \\
\hline & Extracting. Salient & 9920.808 & 1 & 9920.808 & 3425.668 & .000 & .954 \\
\hline & Understanding. Relation. Between. Sentences & 8269.952 & 1 & 8269.952 & 3787.406 & .000 & .958 \\
\hline & Extracting. Relevant & 8099.132 & 1 & 8099.132 & 2806.679 & .000 & .945 \\
\hline & Skimming & 8979.770 & 1 & 8979.770 & 3218.455 & .000 & .952 \\
\hline & Identifying. Main. Point & 7597.569 & 1 & 7597.569 & 3250.873 & .000 & .952 \\
\hline & Scanning & 8826.728 & 1 & 8826.728 & 3788.573 & .000 & .959 \\
\hline \multirow{13}{*}{$\begin{array}{l}\text { Field of } \\
\text { study }\end{array}$} & Deducing. Meaning & 296.754 & 3 & 98.918 & 37.444 & .000 & .407 \\
\hline & Understanding. Information & 68.251 & 3 & 22.750 & 9.905 & .000 & .153 \\
\hline & Distinguishing. Main. Supporting & 124.395 & 3 & 41.465 & 13.286 & .000 & .196 \\
\hline & Understanding. Relation. Sentences & 32.747 & 3 & 10.916 & 4.181 & .007 & .071 \\
\hline & Understanding. Cohesion & 131.367 & 3 & 43.789 & 25.233 & .000 & .316 \\
\hline & Basic. Reference. Skill & 67.933 & 3 & 22.644 & 11.405 & .000 & .173 \\
\hline & Understanding. Conceptual & 23.383 & 3 & 7.794 & 3.669 & .014 & .063 \\
\hline & Extracting. Salient & 57.192 & 3 & 19.064 & 6.583 & .000 & .107 \\
\hline & Understanding. Relation. Between. Sentences & 132.397 & 3 & 44.132 & 20.211 & .000 & .270 \\
\hline & Extracting. Relevant & 52.787 & 3 & 17.596 & 6.098 & .001 & .100 \\
\hline & Skimming & 17.461 & 3 & 5.820 & 2.086 & .104 & .067 \\
\hline & Identifying. Main. Point & 14.420 & 3 & 4.807 & 2.057 & .108 & .066 \\
\hline & Scanning & 17.667 & 3 & 5.889 & 2.528 & .059 & .054 \\
\hline \multirow{13}{*}{ Error } & Deducing. Meaning & 433.243 & 164 & 2.642 & & & \\
\hline & Understanding. Information & 376.701 & 164 & 2.297 & & & \\
\hline & Distinguishing. Main. Supporting & 511.843 & 164 & 3.121 & & & \\
\hline & Understanding. Relation. Sentences & 428.178 & 164 & 2.611 & & & \\
\hline & Understanding. Cohesion & 284.606 & 164 & 1.735 & & & \\
\hline & Basic. Reference. Skill & 325.626 & 164 & 1.986 & & & \\
\hline & Understanding. Conceptual & 348.426 & 164 & 2.125 & & & \\
\hline & Extracting. Salient & 474.947 & 164 & 2.896 & & & \\
\hline & Understanding. Relation. Between. Sentences & 358.101 & 164 & 2.184 & & & \\
\hline & Extracting. Relevant & 473.249 & 164 & 2.886 & & & \\
\hline & Skimming & 457.574 & 164 & 2.790 & & & \\
\hline & Identifying. Main. Point & 383.282 & 164 & 2.337 & & & \\
\hline & Scanning & 382.092 & 164 & 2.330 & & & \\
\hline
\end{tabular}




\section{Discussion}

The results of study indicated that there would be a significant difference in the improvement in reading comprehension of undergraduates of university students before and after receiving reading sub-skills instruction. This supports the findings of most of the studies that were carried out (Cain, Oakhill, \& Lemmon, 2004; Cain \& Towse, 2008; Duggan \& Payne, 2009; Oakhill, 1993; Zwaan \& Brown, 1996).

Understanding the complexity reading comprehension and the aim of the general English course for university students could be explained through an ecological perspective. Perhaps, a broader view of the role of reading comprehension strategies and sub-skills is necessary, particularly in relation to its micro (students' context, classroom context, and university context) and macro (community context) influences. Thus, using Bronfenbrenner's ecosystems framework, the researcher in this study tried to provide a fuller and contextualized understanding of the importance role of teaching reading comprehension strategies. The context of education can be considered as a set of ecosystems, each one nested inside the next (Bronfenbrenner, 1979, 2009). According to Bronfenbrenner (1979), these ecosystems include: micro-, meso-, exo-, and macrosystems. The microsystem exists as the innermost layer, and includes activities, roles, and interpersonal relations experienced by the developing person in a direct interaction. The mesosystem embraces the linkages between two or more settings paving for the developing person. The exosystem involves the interconnection between two or more settings that indirectly influence process within the immediate setting. The macrosystem encompasses the overarching educational and sociocultural factors influencing other ecosystems. In the section below, findings are analyzed regarding the four levels of Bronfenbrenner's model.

\section{Microsystematic Level}

At the microsystem level, students context, classroom context are two important factors.

Student context: At the micro level of educational ecosystem, the needs of individual students are influenced by for what purposes they attend in the general English course. First of all, they are supposed to be prepared for academic English exams like TOLIMO, TELP, and MSRT in which reading comprehension part plays an important role in their performance. Second, they are supposed to look and search for different articles related to their field of study; thus, reading comprehension seems more significant than the other skills like speaking, listening, and writing. However, these needs were not achieved at the pre-test. To remove students' needs, reading comprehension skills was thought to these students and the results of the post-test showed a significant difference in the improvement in reading comprehension of undergraduates of university students.

Classroom context: In the microsystem of the course with the teaching sub-skills reading comprehension (results of the post-test), teachers should select teaching materials, help students to improve their reading comprehension, and make judgments about student learning. Moreover, teachers are expected to teach sub-skills and strategies such as skimming, scanning, guessing unknown words, and so on as part of reading comprehension instruction in the general English courses to remove students' need at this level. However, these roles of the teacher in the microsystem of T-tests were ignored.

Teachers are in a strategic position to help students learn how to approach a reading assignment. They can guide students to analyze the reading task, to make efficient plans for purposeful reading, and to use appropriate strategies to enhance their ability to comprehend and reason from the text. As this study has conclusively demonstrated, the use of these reading comprehension skills can significantly enhance these important components of reading comprehension for students in universities. 


\section{Mesosystematic Level}

The linkage at this level could be found in interconnection between the classroom of general English and universities.

University context: Considering the growth of international relations of Iran with other nations and extended interest towards today's growing technology and science throughout the world, learning English language as an international language has found a greater importance compared to previous years. This sets the stage for more exposure of Iranian students to an academic context in universities. Additionally, university students have more access to academic articles; thus, the need for improvement of reading comprehension skills is felt. According to Maleki and Zangani (2007), one of the most serious problems that Iranian EFL university students face in their field of study is their inability to communicate and handle English after graduating from university. This is due to their weaknesses in general English, which influence their academic success. Having passed some courses and having graduated, Iranian EFL students in general seem not to be as proficient and qualified in language use and components as might be expected (Farhady, Jafarpoor, \& Birjandi, 1994). The results of the pre-test indicated that most students were not familiar with reading comprehension skills. It means that there is a contrast between microsystem (students' real need of learning general English) and mesosystem (universities' policies and materials for teaching general English).

\section{Exosystematic Level}

The link between universities and policy makers in the educational systems can be discussed at this level.

Policy-making at the educational context: Policy makers need information to do their work at the ecosystematic level. School district administrators and school boards develop policies that reflect their knowledge of individual schools and the school system in general. To do so, policy makers at the educational level use assessment data of some especial exams that conducted in Iran such as MSRT and TOLIMO. These Exams are tests to measure the English proficiency of university students at the higher level of education in Iran. In other words, it is required primarily by universities in order to accept students for higher education. These tests recently have the following sections: listening comprehension, structure and written expression, and reading comprehension. Still, there is a sharp contrast between the policy maker objectives at the exosystematic level (i.e., effective reading comprehension in MSRT and TOLIMO exams) on one hand, and instructional materials and policies at the microsystematic level on the other hand.

In order to remove the contrast, policy makers have a responsibility to support and enable the micro-level work of students and educators within their jurisdictions, albeit from a distance, while they concurrently are responsible for the stewardship of community resources and for meeting the multiple and politicized expectations of the electorate.

\section{Macrosystematic Level}

The form of interaction with other societies and community context and can be discussed at the macrosystem level.

Community context: In Iran English is the dominant language of the foreign trade, international conferences, air traffic in international airports, and sea navigation. International book fairs and the trade exhibitions held annually in the country demonstrate the country's readiness and its dependable capacity to maintain its world relationship in English. Iran's cooperation with the UN, Islamic Conference Organization, OPEC, and other regional and world organizations makes English quite practical for the involved nationals. 
Additionally, with growth of the science and technology and development of academic relationship of Iran with the other countries the need for an effective communication is needed. One channel of communication which seems pivotal for the general English language learners at university is reading comprehension for several reasons. However, the result showed that students have weaknesses in reading comprehension due to the lack of influential instruction at the mesosytematic level.

\section{Conclusion}

The present findings suggest that students benefit from strategic reading instruction offered in a university environment. The integrated features of reading comprehension sub-skills instruction appear to have facilitated the development of students' reading comprehension and reading strategy use. University students who develop and apply reading skills could improve their reading comprehension in their content subjects and, therefore, also their academic performance.

However, students cannot be expected to acquire successful reading strategies incidentally, yet many come to our classes without a full realization of what is expected of them. These students consequently continue to use inappropriate strategies with no awareness of the limitations of their habitual way of reading and learning or more productive options for completing academic tasks. We must actively seek and share practices with colleagues that will help our students identify the obstacles that restrict their possibilities in university and equip all of the unique learners who fill our classes with the knowledge and strategies to take action toward transforming that which limits them.

\section{References}

Alderson, J. C. (2005). Assessing reading (5th ed.). Cambridge: Cambridge University Press.

Al-Jarf, R. S. (2001). Processing of cohesive ties by EFL Arab college students. Foreign language annals, 34(2), 141-151.

Anderson, N. J. (1991). Individual differences in strategy use in second language reading and testing. The Modern Language Journal, 75, 460-472.

Anmarkrud, O., Bråten, I., \& Strømsø, H. I. (2014). Multiple-documents literacy: Strategic processing, source awareness, and argumentation when reading multiple conflicting documents. Learning and Individual Differences, 30, 64-76.

Arnold, N. (2009). Online extensive reading for advanced foreign language learners: An evaluation study. Foreign Language Annals, 42(2), 340-366.

Badecker, W., \& Straub, K. (2002). The processing role of structural constraints on interpretation of pronouns and anaphors. Journal of Experimental Psychology: Learning, Memory, and Cognition, 28(4), 748.

Barnett, M. A. (1988). Reading through context: How real and perceived strategy use affects L2 comprehension. Modern Language Journal, 150-162.

Berkowitz, E., \& T. Cicchelli. (2004). Metacognitive strategy use in reading of gifted high achieving and gifted underachieving middle school. Education and Urban Society, 37(1), 37-57.

Block, E. (1992). See how they read: Comprehension monitoring of L1 and L2 readers. TESOL Quarterly, 26(2), 319-343.

Bråten, I., \& Strømsø, H. I. (2011). Measuring strategic processing when students read multiple texts. Metacognition and Learning, 6(2), 111-130.

Bronfenbrenner, U. (1979). The ecology of human development: Experiments by nature and design. Cambridge, Mass: Harvard University Press.

Bronfenbrenner, U. (2009). The ecology of human development: Experiments by nature and design. Harvard: Harvard University Press.

Brown, H. D. (2004). Language assessment: Principles and classroom practices. Boston: Allyn \& Bacon.

Cain, K., \& Towse, A. S. (2008). To get hold of the wrong end of the stick: Reasons for poor idiom understanding in children with reading comprehension difficulties. Journal of Speech, Language, and Hearing Research, 51(6), 1538-1549. 
Cain, K., Oakhill, J., \& Lemmon, K. (2004). Individual differences in the inference of word meanings from context: The influence of reading comprehension, vocabulary knowledge, and memory capacity. Journal of educational psychology, 96(4), 671.

Canale, M., \& Swain, M. (1980). Theoretical bases of communicative approaches to second language teaching and testing. Applied Linguistics, 1(1), 1-47.

Carrell, P. L. (1998). Can reading strategies be successfully taught? Australian Review of Applied Linguistics, 21, 1-20.

Chen, M. H., Gualberto, P. J., \& Tameta, C. L. (2009). The development of metacognitive awareness inventory. TESOL Journal, 1, 43-57.

Chomsky, N. (1964). Aspects of the theory of syntax (DTIC Document).

Crawley, R. A., \& Stevenson, R. J. (1990). Reference in single sentences and in texts. Journal of Psycholinguistic Research, 19(3), 191-210.

Demel, M. C. (1990). The relationship between overall reading comprehension and comprehension of coreferential ties for second language readers of English. TESOL Quarterly, 24(2), 267-292.

Duggan, G. B., \& Payne, S. J. (2009). Text skimming: The process and effectiveness of foraging through text under time pressure. Journal of Experimental Psychology: Applied, 15(3), 228.

Elahi, M. S., \& Taherian, T. (2015). An ecological exploration of the culture of English as an international language among Iranian English language teachers in light of Vygotsky's genotypic approach. Sino-US English Teaching, 12(8), 608-625.

Farhady, H., Jafarpoor, A., \& Birjandi, P. (1994). Language skills testing: From theory to practice. Tehran: Center Studying and Compiling University Books in Humanities, SAMT.

Goodman, K. S. (1967). Reading: A psycholinguistic guessing game. Literacy Research and Instruction, 6(4), 126-135.

Grabe, W. (2009). Reading in a second language: Moving from theory to practice. New York: Cambridge University Press.

Haenggi, D., Gernsbacher, M. A., \& Bolliger, C. M. (1994). Individual differences in situation-based inferencing during narrative text comprehension. Advances in Discourse Processes, 53, 79-96.

Huang, S. (2005). Assessing the relationship between referential understanding and academic reading comprehension among EFL college students (Unpublished master thesis, National Yunlin University of Science and Technology, Taiwan).

Hudson, T. (2007). Teaching second language reading. Oxford: Oxford University Press.

Hymes, D. (1967). Models of the interaction of language and social setting. Journal of Social Issues, 23(2), 8-28.

Hymes, D. (1972). On communicative competence. In Sociolinguistics (pp. 269-293). Harmondsworth: Penguin.

Ikeda, M., \& Takeuchi, O. (2006). Clarifying the differences in learning EFL reading strategies: An analysis of portfolios. System, 34, 384-398.

Kaivanpanah, S., \& Alavi, S. M. (2008). The role of linguistic knowledge in word-meaning inferencing. System, 36(2), $172-195$.

Karbalaei, A. (2010). A comparison of the global reading strategies used by EFL and ESL readers. The Reading Matrix, 10(2), 165-180.

Kennison, S. M. (2003). Comprehending the pronouns her, him, and his: Implications for theories of referential processing. Journal of Memory and Language, 49(3), 335-352.

Kobayashi, K. (2010). Strategic use of multiple texts for the evaluation of arguments. Reading Psychology, 31, 121-149.

Koda, K. (2005). Insights into second language reading: A cross-linguistic approach. Cambridge: Cambridge University Press.

Lee, K. R. (2007). Strategy awareness-raising for success: Reading strategy instruction in the EFL context (Unpublished doctoral dissertation, University of Maryland, College Park).

Levine, A., Ferenz, O., \& Reves, T. (2000). EFL academic reading and modern technology: How can we turn our students into independent critical readers. TESL-EJ, 4(4), 1-9.

Li, F. (2010). A study of English reading strategies used by senior middle school students. Asian Social Science, 6(10), $184-192$.

Maleki, A., \& Zangani, E. (2007). A survey on the relationship between English language proficiency and the academic achievement of Iranian EFL students. Asian EFL Journal, 9(1), 86-96.

Mason, L., Scirica, F., \& Salvi, L. (2006). Effects of beliefs about meaning construction and task instructions on interpretation of narrative text. Contemporary Educational Psychology, 31, 411-437.

McNeil, L. (2011). Investigating the contributions of background knowledge and reading comprehension strategies to L2 reading comprehension: An exploratory study. Reading and Writing, 24, 883-902.

Munby, J. (1978). Communicative syllabus design: A sociolinguistic model for defining the content of purpose-specific language programmers. Cambridge: Cambridge University Press.

Nuttall, C. (2005). Teaching reading skills in a foreign language (2nd ed.). Oxford: Macmillan.

Oakhill, J. (1993). Children's difficulties in reading comprehension. Educational Psychology Review, 5(3), 223-237. 
Oczkus, L. D. (2003). Reciprocal teaching at work strategies for improving reading comprehension. Newark, DE: International Reading Association.

Oxford, R. L. (2003). Language learning styles and strategies: Concepts and relationships. Iral, 41(4), 271-278.

Paris, S. G., Lipson, M. Y., \& Wixson, K. K. (1983). Becoming a strategic reader. Contemporary Educational Psychology, 8(3), 293-316.

Pearson, P. D., Hiebert, E. H., \& Kamil, M. L. (2007). Vocabulary assessment: What we know and what we need to learn. Reading Research Quarterly, 42(2), 282-296.

Poole, A. (2005). Gender differences in reading strategy use among ESL college students. Journal of College Reading and Learning, 36(1), 7-20.

Pretorius, E. J. (2005). English as a second language learner differences in anaphoric resolution: Reading to learn in the academic context. Applied Psycholinguistics, 26(4), 521-539.

Rose, E. (2011). The phenomenology of on-screen reading: University students' lived experience of digitised text. British Journal of Educational Technology, 42(3), 515-526.

Rupp, A. A., Ferne, T., \& Choi, H. (2006). How assessing reading comprehension with multiple-choice questions shapes the construct: A cognitive processing perspective. Language testing, 23(4), 441-474.

Serafini, F. (2004). Lessons in comprehension: Explicit instruction in the reading workshop. Portsmouth, NH: Heinemann.

Sweet, A. P., \& Snow, C. E. (2003). Rethinking reading comprehension. New York, NY: The Guilford Press.

Van Wyk, A. L. (2001). The development and implementation of an English language and literature programme for low-proficiency tertiary learners. Publisher not identified.

Wolf, F., Gibson, E., \& Desmet, T. (2004). Discourse coherence and pronoun resolution. Language and Cognitive Processes, 19(6), 665-675.

Wood, E., Motz, M., \& Willoughby, T. (1998). Examining students' retrospective memories of strategy development. Journal of educational psychology, 90(4), 698.

Zhang, L. J., \& Anual, S. B. (2008). The role of vocabulary in reading comprehension: The case of secondary school students learning English in Singapore. RELC Journal, 39(1), 51-76.

Zhang, L. J., \& Wu, A. (2009). Chinese senior high school EFL students' metacognitive awareness and reading-strategy use. Reading in a Foreign Language, 21(1), 37-59.

Zwaan, R. A., \& Brown, C. M. (1996). The influence of language proficiency and comprehension skill on situation-model construction. Discourse Processes, 21(3), 289-327. 